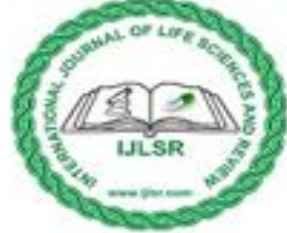

Received on 20 October 2015; received in revised form, 21 November 2015; accepted, 29 November 2015; published 30 November 2015

\title{
LIPID BASED DRUG DELIVERY SYSTEM: A REVIEW
}

\author{
Dilpreet Singh
}

Department of Pharmaceutical Sciences, Guru Nanak Dev University, Amritsar - 143005, Punjab, India.

\begin{abstract}
Poor solubility remains one of the more challenging and critical tasks in drug discovery and development, and it is also the main cause of low bioavailability and poor therapeutic efficacy of the drug. Many solubility enhancement techniques are available in literature like cyclodextrin inclusion complexes, salt formation, solid dispersion, drug delivery carrier approach and prodrug approach are useful, but the most widely used technique for enhancing the solubility of poorly soluble drugs is by encapsulating the drug is lipid-based excipients, which enhances solubilization of the drug in excipient matrix, lead to enhanced bioavailability and improved therapeutic efficacy. Many lipid-based drug delivery systems are available like self-emulsifying drug delivery system (SEDDS), liposomes, solid lipid nanoparticles, nanostructured lipid carrier, which are widely used for lipophilic drugs. In this review, we highlighted some novel mechanisms for drug absorption through lipid-based systems and its commercial applications in the pharmaceutical and biological field.
\end{abstract}

Keywords: Bioavailability, Lipid excipients, SEDDS, Vitamin E

\section{Correspondence to Author:}

Dilpreet Singh

Department of Pharmaceutical Sciences, Guru Nanak Dev University, Amritsar - 143005, Punjab, India.

E-mail: dilpreet.daman@gmail.com

INTRODUCTION: About $70 \%$ of all new chemical entities (NCE) possess poor aqueous solubility, which causes poor absorption in the GI tract, leads to poor bioavailability. The main causes of poor bioavailability are given in Fig. 1. The FDA has divided the new chemical entities into four groups and classified by their aqueous solubility and permeability and give the name as biopharmaceutical classification system ${ }^{1,2}$ Fig. 2 . The poorly aqueous soluble drugs are also complicated by their variable effect on fed conditions (food effect) which causes more problems in absorption leads to complicated delivery to the targeting area.

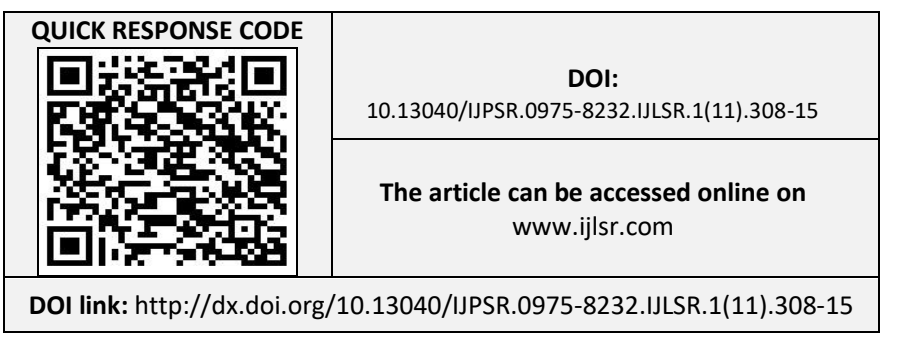

International Journal of Life Sciences and Review
This type of formulations will produce more toxicity, making the formulations more costly and difficult. In the era of modern drug delivery, formulation scientists will realize that the poor oral bioavailability will enhance when co-administered in high-fat meal leads to more interest in lipids as a means of solubilizing the drugs in the GI tract ${ }^{3,4}$.

Lipids are the group of naturally occurring molecules, including fats (triglycerides), waxes (beeswax, aliphatic hydrocarbons), sterols (Cholesterol, phospholipids) and fat-soluble vitamins (Vitamin A, D, E, and K). The biological function of lipids as storing energy in the body and the main structural component of cell membrane 5 , $6,7,8$. The pharmaceutical importance of lipids in enhancing the absorption of poorly soluble drugs are governed by many mechanisms, including increasing chylomicron production and stimulation of lymphatic transport, alteration (reduction) in gastric transit, preventing drug absorption on intestinal dilution and increasing membrane 
permeability. Various lipids are used in drug delivery, including oils (Vitamin E, Captex oil), surfactants (Polysorbate 80, Polyethoxylated 35 castor oil) and all the medium and long-chain triglycerides. Various types of lipid-based drug delivery systems have been used widely like Self emulsifying drug delivery system (SEDDS), solid lipid nanoparticles, microemulsion, nanoemulsion, liposomes and nanostructured lipid carrier for solubilizing the poorly soluble drugs Fig. 3 this review highlighting the main features of lipid-based drug delivery system and their commercial applications in pharmaceutical industry $9,10,11,12$.

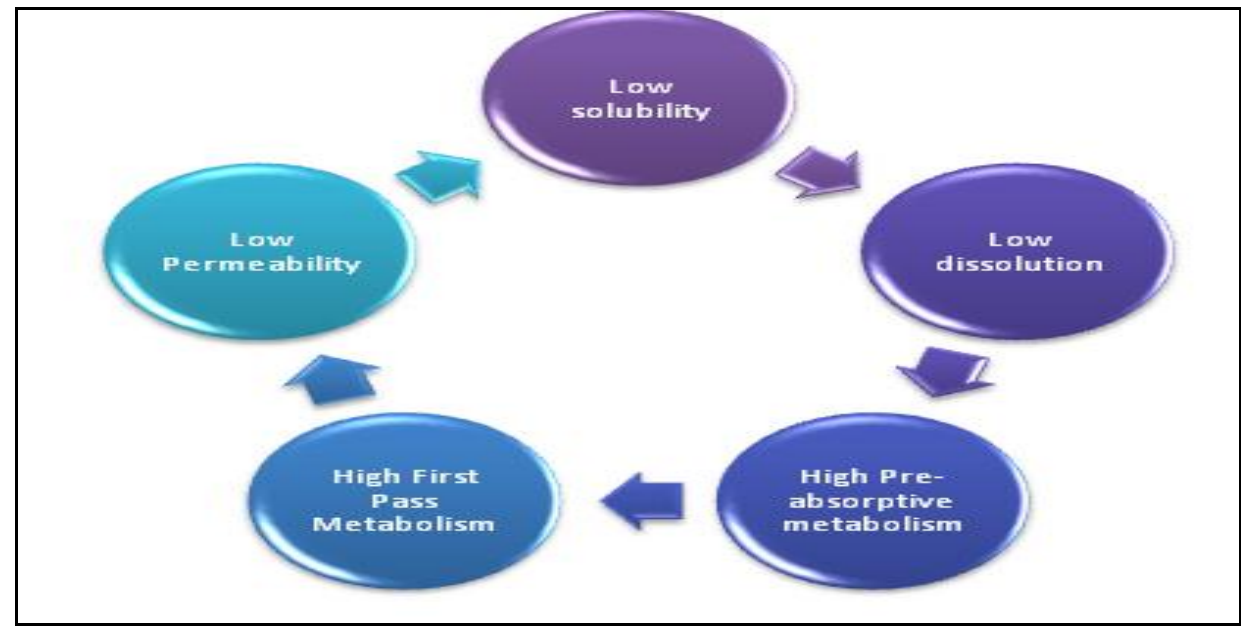

FIG. 1: CAUSES OF POOR ORAL BIOAVAILABILITY

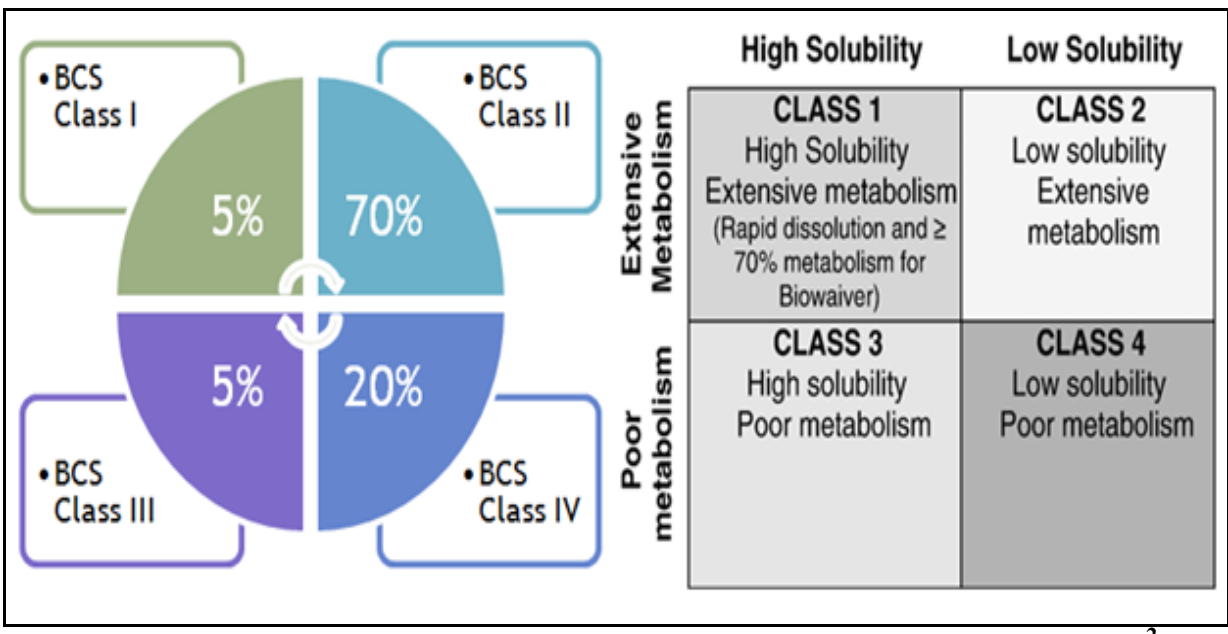

FIG. 2: THE BIOPHARMACEUTICAL CLASSIFICATION SYSTEM ${ }^{2}$

Lipid Formulation Classification System: Lipids are broadly classified into 4 types based upon their particle size, role in drug delivery, composition, characteristic features are their commercial applications. Lipid formulation classification systems play a vital role in selecting the required lipid excipient in selected formulation ${ }^{13,14}$.

TABLE 1: THE MAIN FEATURES OF LIPID BASED CLASSIFICATION SYSTEM ARE GIVEN

\begin{tabular}{|c|c|c|c|c|c|}
\hline LFCS Class & Characteristics & Composition & HLB & Impact of dispersion & Examples \\
\hline Type I & Pure oils & Oils & N/A & No dispersion & Dutaseride (Avodart) \\
\hline Type II & $\begin{array}{l}\text { SEDDS } \\
\text { (Low HLB) }\end{array}$ & $\begin{array}{c}\text { Oils plus surfactant } \\
(4: 1)\end{array}$ & $<12$ & $\begin{array}{l}\text { Moderate, forms emulsion } \\
\qquad(>250 \mathrm{~nm})\end{array}$ & $\begin{array}{l}\text { Alfacalcidol } \\
\text { (One-Alpha) }\end{array}$ \\
\hline Type IIIA & $\begin{array}{c}\text { SMEDDS } \\
\text { (Intermediate HLB) }\end{array}$ & $\begin{array}{l}\text { Mixture with additional } \\
\text { Co-surfactant }(20-50 \%)\end{array}$ & $>12$ & $\begin{array}{l}\text { Rapid dispersion to form } \\
\text { micro-emulsion (100nm) }\end{array}$ & $\begin{array}{c}\text { Ritonavir } \\
\text { (Norvir) }\end{array}$ \\
\hline Type IIIB & SNEDDS (High HLB) & $\begin{array}{l}\text { Mixture with additional } \\
\text { Co-solvent }(40 \%)\end{array}$ & $>12$ & $\begin{array}{l}\text { Rapid dispersion to form } \\
\text { nano -emulsion }(<100 \mathrm{~nm})\end{array}$ & $\begin{array}{l}\text { Cyclosporine } \\
\text { (Neoral) }\end{array}$ \\
\hline Type-IV & Oil free & $\begin{array}{c}\text { Surfactant: Cosurfantant } \\
(4: 1)\end{array}$ & $>14$ & $\begin{array}{l}\text { Rapid dispersion to form a } \\
\text { micellar solution }(<100 \mathrm{~nm})\end{array}$ & $\begin{array}{l}\text { Amprenavir } \\
\text { (Agenerase) }\end{array}$ \\
\hline
\end{tabular}




\section{Advantages of Lipid Based Drug Delivery Systems: ${ }^{15,16}$}

- Lipid-based formulations solubilize the drug in excipient matrix leads to a substantial increase in drug solubilization as compare to the conventional formulation.

- Eliminates variability associated with reliance on GIT for solubilisation.

- Reduction/elimination of food effect.

- Does not require modification to NCE molecular structure.

- Solvent-free formulation process.

- Pharmaceutical grade excipients and manufacturing equipment readily available.

Role of Lipid-Based Drug Delivery System in Critical Oral Absorption: The oral drug absorption is one of the main factors in designing lipid-based drug delivery systems. The main challenges in critical oral drug absorption are gastric emptying, intestinal transit, dissolution, intestinal based efflux metabolism (cytochrome $\mathrm{P} 450$ isoenzymes) and lymphatic transport.

These barriers will limit oral drug absorption in many ways like low solubility, poor dissolution, high first-pass metabolism, and high efflux drug transportation. The lipid-based system is designed to tackle these barriers, which lead to enhance bioavailability and provide the improved systemic drug circulation in the body ${ }^{17,18}$. The main factors in oral drug absorption and the role of lipids influencing these factors are described in Fig. 3.

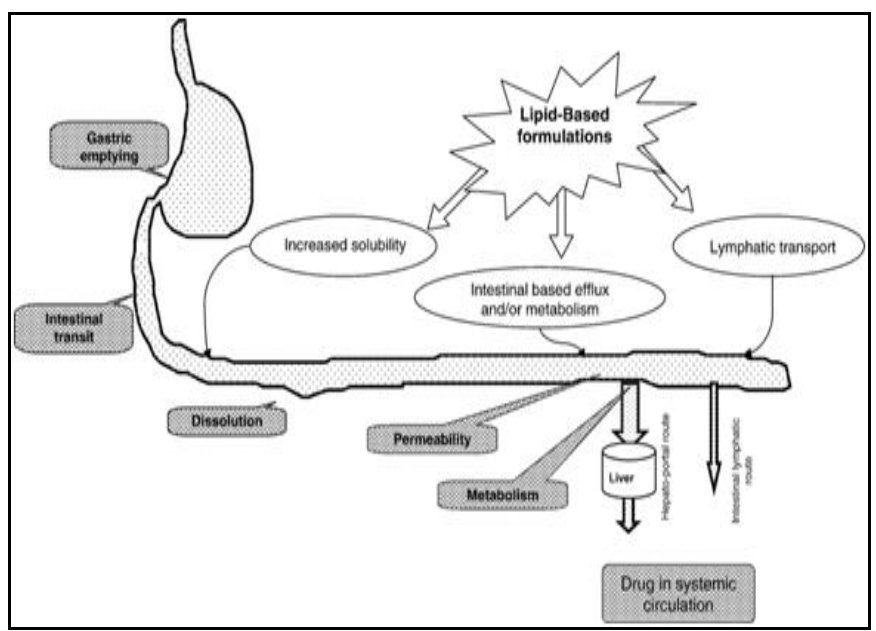

FIG. 3: ROLE OF LIPIDS BASED FORMULATIONS IN CRITICAL ORAL DRUG ABSORPTION
Mechanism of Absorption Enhancement: The lipid formulation in a soft gelatin capsule is first taken orally goes in the stomach where the exogenous lipids convert triglycerides to monoglycerides to free fatty acids by the action of gastric enzyme lipase; this process is known as initial lipid emulsification. The dispersed formulation then goes into the intestine, where pancreatic lipase and co-lipase completes the breakdown of lipids to free fatty acids. These free fatty acids will stimulate the release of bile salts (Phospholipids and cholesterol) in the gallbladder, which combines with lipid digestion products to produce mixed micelles. These mixed micelles contain poorly water-soluble drugs goes into absorption and then into the systemic circulation ${ }^{19}$, $20,21,22,23$. Some phospholipids and cholesterol absorb into the surface of emulsion droplets and produces small stable droplets which produce solubilization of lipids. The mixed micelles will provide a lipid environment (lipid solutionemulsion droplet-core of vesicular and micellar phases) which will enhance lymphatic transport of drugs $24,25,26,27,28$.

In general, there are three mechanisms where lipids enhance the absorption of poorly soluble drugs:

- Increases in Effective Luminal Drug Solubility: The presence of lipids in the formulation increases the secretion of bile salts and endogenous lipids (Cholesterol, phospholipids) which forms mixed micelles, which leads to solubilizing effect.

- Alteration (Reduction in Gastric Transit): Reduction in gastric transit leads to slow delivery to the absorptive site and increasing the time available for dissolution

- Stimulation of Intestinal Lymphatic Transport: For highly lipophilic drugs, drugs may enhance the extent of lymphatic transport through inhibition of cytochrome P450 enzymes and P-glycoprotein which is the main transporters for influencing the first pass metabolism ${ }^{29}$.

Lipid-Based Systems and Excipients: A wide variety of lipid-based systems have been explored and its broadly classified into three types- emulsion based system, vascular system, and particulate lipid system. These systems have the potential to 
solubilize the poorly water-soluble drug in a controlled manner. Each system has its mechanism for solubilization of poorly soluble drugs $31,32,33$. The classification of lipid-based drug delivery systems is given in Fig. 4.

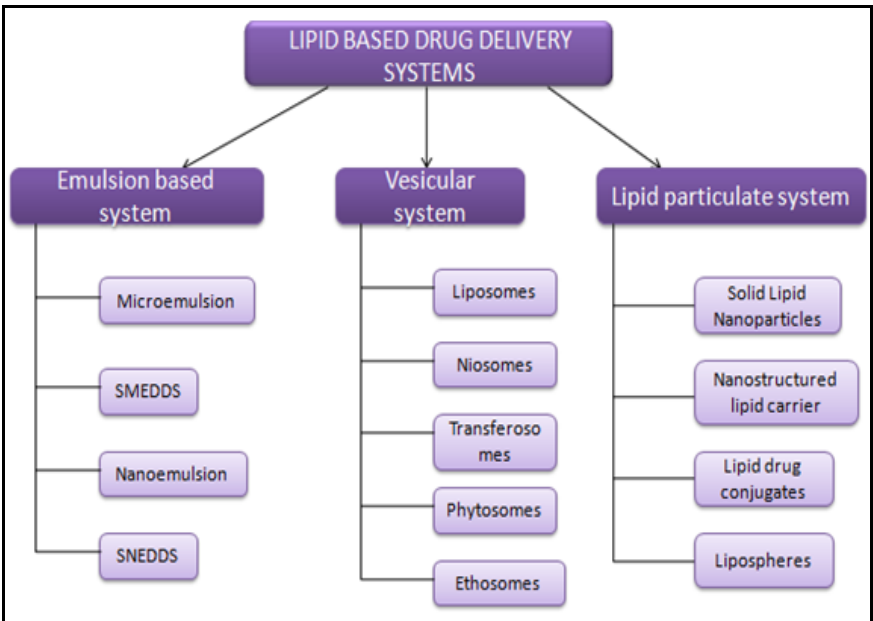

FIG. 4: CLASSIFICATION OF LIPID BASED DRUG DELIVERY SYSTEM

The selection of lipid excipient is a crucial factor in designing the lipid-based drug delivery system. The key formulation factors for lipids and lipophilic excipients are given below:

A) Pharmaceutical Factors: The pharmaceutical factors like solvent capacity, impurity profiling and solid state properties like whether the excipient are solid, semi-solid and liquid are considered for selecting the right excipient in the formulation.
B) In-vivo Solubilization Properties: The proper should maintain the drug solubilization on digestion and well as maintain drug solubilization on dispersion.

C) Biochemical Properties: The lipid-based formulations are designed to buy pass the first pass metabolism by inhibiting the cytochrome enzymes and P-glycoprotein, which is the main transporter responsible for metabolism and enhances the lymphatic transport of poorly water-soluble drugs 34 .

\section{Lipids are broadly classified into 3 Types:}

1. Natural Product Oils: Natural oils or triglycerides containing fatty acids of varying chain length and degree of unsaturation are considered. Examples include castor oil, linseed oil, olive oil.

2. Semi-Synthetics: These excipients having specific physiochemical properties for formulation and are widely used in commercial formulations. Examples include hydrogenated glycerides and macrogol glycerides.

3. Synthetic Lipids: These lipids are considered as surfactants which promote self-emulsification and produces solubilization of drugs through micelles formation. Examples include Vitamin E TPGS, Labrasol etc.

\section{TABLE 2: VARIOUS LIPID EXCIPIENTS USED IN COMMERCIAL FORMULATIONS ${ }^{35,36}$}

\begin{tabular}{|c|c|c|}
\hline Water-insoluble excipients & Triglycerides & Surfactants \\
\hline Bees were oleic acid, soy fatty & Long chain triglycerides. Hydrogenated & Polysorbate 20,80 (Tweens) \\
\hline acids D- $\alpha$-tocopherol (Vitamin & soybean oil, corn oil, olive oil, sesame & D- $\alpha$-tocopherol-PEG-1000 succinate \\
\hline E) corn oil mono-di-glycerides & oil, peanut oil. Medium chain & (Vitamin E TPGS) polyoxy 35 castor oil \\
\hline propylene glycol esters of fatty & triglycerides caprylic triglycerides & (Cremophor EL) PEG 400caprylic /capric \\
\hline acids medium chain triglycerides & obtained from coconut oil or palm & glycerides (Labrasols) sorbitan monolaurate \\
\hline & seed oil & $(\operatorname{Span} 20)$ \\
\hline
\end{tabular}

TABLE 3: FORMULATION TECHNIQUES FOR LIPID BASED EXCIPIENTS ${ }^{35,36}$

\begin{tabular}{ccccc}
\hline $\begin{array}{c}\text { Formulation techniques } \\
\text { for lipid-based } \\
\text { formulations }\end{array}$ & \multicolumn{2}{c}{ Type of the lipid excipient applied } & \multicolumn{2}{c}{ Formulation limits (\% w/w) } \\
\cline { 2 - 5 } & Liquid & $\begin{array}{c}\text { Semi-solid } \\
\text { to solid }\end{array}$ & $\begin{array}{c}\text { Maximum lipid } \\
\text { Exposure (\% w/w) }\end{array}$ & $\begin{array}{c}\text { Maximum drug } \\
\text { Loading (\% w/w) }\end{array}$ \\
\hline Capsule filling & $\checkmark$ & $\checkmark$ & 99 & 50 \\
Spray cooling & $\checkmark$ & $\checkmark$ & 99 & 50 \\
Spray drying & $\checkmark$ & $\checkmark$ & 60 & 50 \\
Adsorption on a solid carrier & $\checkmark$ & $\checkmark$ & 80 & 10 \\
Melt granulation & $\checkmark$ & $\checkmark$ & 50 & 80 \\
Melt extrusion & $\checkmark$ & $\checkmark$ & 50 & 60 \\
Solid lipid nanoparticles & $\checkmark$ & $\checkmark$ & 90 & 50 \\
\hline
\end{tabular}




\section{Formulation Techniques:}

Single Component Lipid Solutions: The simplest technique of lipid-based drug delivery comprises of a drug encapsulated in a single lipid excipient. Most commonly used excipient are polyethylene glycols (PEG), or triglycerides. This type of formulation technique depends upon the gastrointestinal capacity to solubilize lipid, and the chances of drug precipitation are high due to its high solubilizing power for poorly soluble drugs. Most commercially based lipid formulations are composed of single component lipid solutions

Self-Emulsifying Formulations: Self-emulsifying drug delivery system (SEDDS) is the thermodynamically stable isotropic mixtures of oil, surfactant, and co-surfactant, that spontaneously forms an emulsion when it's in contact with aqueous fluid in the GI tract. Depending upon the particle size of emulsion droplet, it is classified as SMEDDS (self micro emulsifying drug delivery system) or SNEDDS (Self nanoemulsifying drug delivery system). SMEDDS are a widely used system to solubilize the hydrophobic drugs by partitioning into two phases (oil phase and aqueous phase), which leads to enhance bioavailability. Tacrolimus is a poorly water-soluble drug (1.0 $\mathrm{ug} / \mathrm{ml}$ ), and poor immunosuppressant activity after oral administration, when formulated in SMEDDS will lead to 3 folds higher bioavailability and improved immunosuppressant activity ${ }^{37,38}$.

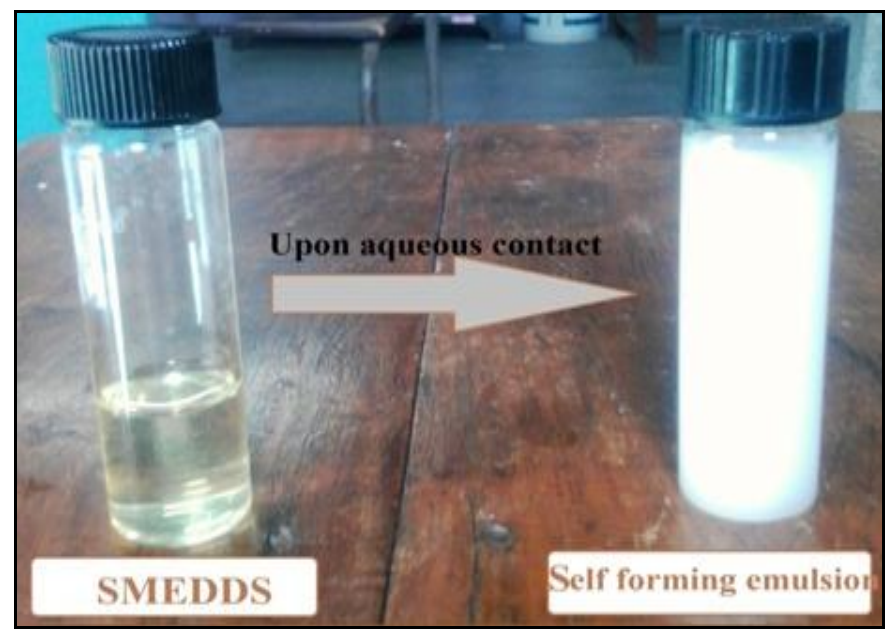

FIG. 5: CONVERSION OF SMEDDS TO FORMING EMULSION WHEN IT CONTACT WITH AQUEOUS FLUID

Self-emulsifying solid dispersion formulations: These formulations consists of a drug; which is in the finely divided crystalline state, encapsulated in an inert excipient matrix leads to enhance dissolution and subsequent in the GI tract. This type of formulation depends on the micellar cosolvent systems to fully solubilize the drug. These formulations will not be useful commercially due to its poor solubilization capacity and poor stability after storing in extreme conditions

\section{Commercial Applications:}

Biotechnology Based Therapeutics: Certain biological based therapeutics like peptides (insulin), vaccines and hormones are chemically known as macromolecules and are ineffective orally due to its degradation by gastric enzymes or its high molecular weight nature.

Lipid-based drug delivery system has the potential to overcome these issues. Testosterone given orally is ineffective in treating androgen deficiency due to its poor oral bioavailability and high systemic first pass metabolism. The lipophilic undecanoate ester has improved oral bioavailability and given orally provide improved androgen activity and less systemic metabolism ${ }^{40}$.

Liposomes: Liposomes are lipid-based unilamellar vesicles that are having the capability to encapsulate the drug in the hydrophobic region in the liposomal matrix.

Amphotericin B solubility is just $1.0 \mu \mathrm{g} / \mathrm{ml}$ (Poorly water soluble) have increased the frequency of administration and have severe side effects after oral administration Commercially available liposomal formulation known as fungisome $\AA$ have bioavailability 3 folds higher $(80-85 \%)$ and have reduced side effects after oral administration ${ }^{41,42}$.

\section{Self Micro Emulsifying Drug Delivery System} (SMEDDS): SMEDDS are the isotropic mixtures of oil, surfactant, and co-surfactant, when exposes to aqueous fluid in the GI tract, it spontaneously forms an emulsion.

Saquinavir is an HIV protease inhibitor is first available commercial in mesylate salt formulation known as Invirase ${ }^{\circledR}$ have poor oral bioavailability $(10 \%)$, the drug is encapsulated in commercially available lipid-based SMEDDS and formulated in hard gelatin capsule known as forvotrase ${ }^{\circledR}$ have bioavailability 3 folds higher $(85 \%)^{43}$. 
TABLE 4: RECENT PATENTS ON LIPID BASED DRUG DELIVERY SYSTEMS

\begin{tabular}{|c|c|c|c|}
\hline Patent number & Inventor & Publishing date & Abstract \\
\hline US5906831A & $\begin{array}{l}\text { Kare Larsson, } \\
\text { Helena Ljusberg- } \\
\text { Wahren }\end{array}$ & $06-03-2002$ & $\begin{array}{l}\text { The present invention deals with Controlled release composition } \\
\text { of a biologically active material composed of manocaproin that } \\
\text { forms reversed micelles structure or a normal micellar structure }\end{array}$ \\
\hline WO2003013608A1 & $\begin{array}{l}\text { Francis Vanderbist, } \\
\text { Arthur Deboeck, } \\
\text { Philippe Baudier, } \\
\text { Antonio Sereno }\end{array}$ & $20-02-2003$ & $\begin{array}{c}\text { The present invention deals with an oral lipid-based } \\
\text { pharmaceutical composition containing a PPAR } \alpha \text { and an } \\
\text { HMG-COA reductase inhibitor for the treatment of } \\
\text { hypercholesterolemia }\end{array}$ \\
\hline US20110039814A1 & $\begin{array}{l}\text { Hiep Huatan } \\
\text { Richard Ross }\end{array}$ & 27-04-2009 & $\begin{array}{l}\text { The invention relates to pharmaceutical compositions adapted for } \\
\text { oral delivery and set the dose frequency according to the circadian } \\
\text { rhythm, and including methods for the treatment of hormone- } \\
\text { related conditions } 46\end{array}$ \\
\hline US5635536A & Robert T. Lyons & 06-03-2007 & $\begin{array}{c}\text { An acid emulsion comprising a lipid dispersed in an aqueous } \\
\text { phase, a cationic sphingolipid, and a required amount of non-ionic } \\
\text { surfactant and cholesterol is provided, along with the method of } \\
\text { administering the emulsion } 47\end{array}$ \\
\hline US5993858A & $\begin{array}{c}\text { John R. Crison } \\
\text { Gordon L. Amidon }\end{array}$ & 30-11-1999 & $\begin{array}{l}\text { The present invention deals with lipid-based formulation for } \\
\text { increasing the bioavailability of a poorly soluble drug which } \\
\text { includes an oil phase or other lipid material, a } \\
\text { surfactant }(\text { HLB }<12) \text { and a hydrophilic co-surfactant }\end{array}$ \\
\hline US6368620B2 & $\begin{array}{l}\text { Rong Liu, } \\
\text { Qinghai Pan, } \\
\text { Dennis Lee }\end{array}$ & 09-04-2002 & $\begin{array}{l}\text { The present invention is related to prepare a formulation } \\
\text { comprising a lipid-regulating agent dissolved in a supercritical } \\
\text { fluid and then spray it to form the solution through a nozzle to } \\
\text { form small particle and forming a suspension of the particles of } \\
\text { lipid-regulating agent in a liquid, and collecting the particles }\end{array}$ \\
\hline WO2000057859A1 & $\begin{array}{l}\text { Jitendra P Patel } \\
\text { Yeshwant D Sanzgiri } \\
\text { John M Lipari } \\
\text { Thomas L Reiland }\end{array}$ & $05-10-2000$ & $\begin{array}{l}\text { The present invention is directed to a formulation comprising a } \\
\text { lipid-regulating agent dispersed in at least one oil and an } \\
\text { emulsifier, the resulting mixture being capable of spontaneously } \\
\text { forming an emulsion upon contact with an aqueous medium }{ }^{50}\end{array}$ \\
\hline
\end{tabular}

TABLE 5: COMMERCIAL FORMULATIONS OF LIPID BASED SYSTEMS ${ }^{39}$

\begin{tabular}{|c|c|c|c|c|}
\hline Marketed formulation & Drug name & indication & Dosage form & Company \\
\hline Norvir® & Ritonavir & $\begin{array}{c}\text { Antiretroviral } \\
\text { (protease inhibitor) }\end{array}$ & $\begin{array}{l}\text { Soft gelatin capsule } \\
\text { (SGC) }\end{array}$ & $\begin{array}{c}\text { Abbott } \\
\text { Laboratories }\end{array}$ \\
\hline fortovase $₫$ & saquinavir & $\begin{array}{c}\text { Antiretroviral } \\
\text { (protease inhibitor) }\end{array}$ & $\begin{array}{l}\text { Soft gelatin capsule } \\
\text { (SGC) }\end{array}$ & $\begin{array}{l}\text { Hoffman-La } \\
\text { Roche Inc. }\end{array}$ \\
\hline Agenerase ${ }^{\circledR}$ & Amprenavir & $\begin{array}{c}\text { Antiretroviral } \\
\text { (protease inhibitor) }\end{array}$ & $\begin{array}{l}\text { Soft gelatin capsule } \\
\text { (SGC) }\end{array}$ & $\begin{array}{l}\text { Glaxo smith kline } \\
\text { (GSK) }\end{array}$ \\
\hline Rocaltrol® & Calcitriol & Calcium regulator & Soft gelatin capsule (SGC) & Roche \\
\hline convulex® & Valproic acid & $\begin{array}{l}\text { Anticonvulsant and mood- } \\
\text { stabilizing drugs }\end{array}$ & $\begin{array}{l}\text { Soft gelatin capsules } \\
\text { (SGC) }\end{array}$ & Pharmacia \\
\hline Lipirex® & Fenofibrate & $\begin{array}{c}\text { Hypolipidaemic drug } \\
\text { (Activate lipoprotein lipase) }\end{array}$ & $\begin{array}{c}\text { Hard gelatin capsule } \\
\text { (HGC) }\end{array}$ & Genus \\
\hline Accutane ${ }^{\circledR}$ & Isotretinoin & $\begin{array}{c}\text { Antiacne (cell differentiation } \\
\text { and apoptosis) }\end{array}$ & $\begin{array}{l}\text { Soft gelatin capsule } \\
\text { (SGC) }\end{array}$ & Roche \\
\hline Avodart ${ }^{\circledR}$ & Dutaseride & $\begin{array}{l}\text { benign prostatic hyperplasia } \\
\text { (5- } \alpha \text { reductase inhibitor) }\end{array}$ & $\begin{array}{l}\text { Soft gelatin capsule } \\
\text { (SGC) }\end{array}$ & $\begin{array}{l}\text { Glaxo smith } \\
\text { kline(GSK) }\end{array}$ \\
\hline Coreg CR & $\begin{array}{l}\text { Carvedilol } \\
\text { phosphate }\end{array}$ & $\begin{array}{l}\text { Hypertension } \\
(\beta \text {-Blocker })\end{array}$ & $\begin{array}{l}\text { Hard gelatin capsule } \\
\text { (HGC) }\end{array}$ & $\begin{array}{l}\text { Glaxo smith } \\
\text { kline(GSK) }\end{array}$ \\
\hline Detrol LA & Tolterodine & $\begin{array}{l}\text { urinary incontinence } \\
\text { ( anti muscarinic drug) }\end{array}$ & $\begin{array}{l}\text { Soft gelatin capsule } \\
\text { (SGC) }\end{array}$ & Pharmacia \\
\hline Aptivus & Tipranavir & $\begin{array}{c}\text { HIV } \\
\text { Antiviral }\end{array}$ & $\begin{array}{l}\text { Soft gelatin capsule } \\
\text { (SGC) }\end{array}$ & $\begin{array}{l}\text { Boehringer } \\
\text { Ingelheim }\end{array}$ \\
\hline Vesanoid & Tretinoin & Acute promyelocytic leukemia & Soft gelatin capsule (SGC) & Roche \\
\hline
\end{tabular}


ACKNOWLEDGEMENT: Nil

\section{CONFLICT OF INTEREST: Nil}

\section{REFERENCES:}

1. Amidon GL, Lennernas H, Shah VP and Crison JR;: A theoretical basis for a biopharmaceutic drug classification: the correlation between in vitro drug product dissolution and in-vivo bioavailability. Pharm Res 1995; 12: 413-420.

2. Website:http://www.fda.gov/aboutfda/centersoffices/office ofmedicalproductsandtobacco/cder/ucm128219.htm

3. Fleisher D, Li C, Zhou Y, Pao LH and Karim A: Drug, meal and formulation interactions are influencing drug absorption after oral administration and clinical implications. Clin Pharmacokin 1999; 36: 233-254.

4. Winstanley PA and Orme MLE: The effect of food on drug oral bioavailability. Br J Clin Pharmacol 1989; 28: 621-628

5. Pouton CW: Lipid formulations for oral administration of drugs: non-emulsifying, Self-emulsifying, and self-micro emulsifying drug delivery systems. Eur J Pharm Sci 2000; 11: S93-S98

6. Gursoy RN and Benita S: Self-emulsifying drug delivery systems (SEDDS) for improved oral delivery of lipophilic drugs. Biomed Pharmacother 2004; 58: 173-182.

7. David J and Hauss: Oral lipid-based formulations. Adv Drug Deliv Rev 2007; 59: 667-676.

8. Porter CJ and Charman WN: In-vitro assessment of oral lipid-based formulations. Adv Drug Deliv Rev 2001; 50: 127-47.

9. Fricker J, Kromp T, Wendel A and Blume A: Phospholipids and lipids based formulations in oral delivery. Pharm Res 2010; 27: 1469-1486.

10. Jannin V, Musakhanian J and Marchand J: Approaches for the development of solid and semi-solid lipid formulations. Adv Drug Deliv Rev 2008; 60: 734-746.

11. Humberstone AJ and Charman WN: Lipid-based vehicles for oral delivery of lipophilic drugs. Adv Drug Deliv Rev 1997; 25: 390-395.

12. Shrestha H, Bala R and Arora S: Lipid-based drug delivery systems. J Pharm (Hindawi Publishing Corporation) 2014; 34: $1-10$.

13. Wasan KM: Formulation and physiological and biopharmaceutical issues in the development of oral lipidbased drug delivery systems, Drug. Dev Ind Pharm 2001; 27: $267-276$

14. Christopher JH, Natalie L and Charman WN: Lipids and lipid-based formulations: optimizing the oral delivery of lipophilic drugs. Nature Rev 2007; 6: 231-245.

15. Benet LZ, Izumi T, Zhang Y, Silverman JA and Wacher VJ: Intestinal MDR transport proteins and P-450 enzymes as barriers to oral drug delivery. J Controlled Release 1999; 62: 25-31.

16. Porter $\mathrm{CJ}$ and Charman WN: Intestinal lymphatic drug transport: an update. Adv Drug Deliv Rev 2001; 50: 61-80.

17. Porter JH, Pouton CW, Charman WN and Cuine JF: Enhancing intestinal drug solubilisation using lipid-based delivery systems. Adv Drug Deliv Rev 2010; 647: 171-77.

18. Pouton CW: Formulation of poorly water-soluble drugs for oral administration: physicochemical and physiological issues and the lipid formulation classification system. Eur J Pharm Sci 2006; 29: 278-287.

19. Constantinides PP: Lipid microemulsions for improving drug dissolution and oral absorption: physical and biopharmaceutical aspects. Pharmaceutical Research 1995; 12: $1561-1572$.

20. Thomson ABR, Keelan M, Garg ML and Clandinin MT: Intestinal aspects of lipid absorption: in review. Can J Physiol Pharmacol 1989; 67: 179-191.

21. Parmod K, Peeyush K, Rajeev $K$ and Nitish K: An overview of lipid-based formulations for oral drug delivery. Drug Inv Today 2010; 2: 390-395.

22. Wilson CG and Mahony BO: The behavior of oils and fats in the upper GI tract. Bull Tech Gattefosse 1997; 86: 269282.

23. Driscoll CMO: Lipid-based formulations for intestinal lymphatic delivery. Eur J Pharm Sci 2002; 6: 231-248.

24. Carey MC, Small DM and Bliss CM: Lipid digestion and absorption. Ann Rev Physiol 2001; 45: 651-677.

25. Yeh PY: Effect of medium chain glycerides on physiological properties of rabbit intestinal epithelium in vitro. Pharm Res 1994; 11: 1148-1154.

26. Charman WN and Stella VJ: Transport of lipophilic molecules by the intestinal lymphatic system. Adv Drug Deliv Rev 1991; 7: 1-14.

27. Erlanson-Albertsson C: Pancreatic co-lipase: Structural and physiological aspects. Biochem Biophys Acta 1992; 1125: 1-7.

28. Borgstrom B: On the mechanism of pancreatic lipolysis of glycerides. Biochim. Biophys Acta 1954; 13: 491-504.

29. Constantinides PP and Wasan KM: Lipid formulation strategies for enhancing. Intestinal transport and absorption of P-glycoprotein (P-gp) substrate drugs: Invitro/in-vivo case studies. J Pharm Sci 2007; 96: 235-248.

30. Alepu S, Mohanvarma M and Padavala V: Oral lipidbased formulations. Acta Pharmaceutica 2013; 3(6): 361372.

31. Dressman JB, Alsenz J, Schamp K and Beltz K: Oral Lipid-based formulations: enhancing the bioavailability of poorly water-soluble drugs, Informa Healthcare, Inc, New York, 2007; 25: 242-245.

32. Strickley RG: solubilizing excipients in oral and injectable formulations. Pharm Res 2004; 2(2): 201-230.

33. Chen ML: Lipid excipients and delivery systems for pharmaceutical development: a regulatory perspective. Adv Drug Deliv Rev 2008; 60(6): 768-787.

34. Cornaire G, Woodley J, Hermann P, Cloare A, Arellano C and Houin G: Impact of excipients on the absorption of Pglycoprotein substrates in-vitro and in-vivo. Int $\mathrm{J}$ Pharm 2004; 278: 119-131.

35. Jannin V, Musakhanian $\mathbf{J}$ and Marchaud D: Approaches for the development of solid and semisolid lipid-based formulations. Adv Drug Deliv Rev 2008; 60: 734-746.

36. Bowtle WJ: Materials, process, and manufacturing considerations for lipid-based hard-capsule formats, in D.J. Hauss (Ed.), Oral Lipid-Based Formulations - Enhancing the Bioavailability of Poorly Water-Soluble Drugs, Informa Healthcare, New York, 2007: 79-106.

37. Borhade V, Nair H and Hedge D: Design and evaluation of self-micro emulsifying drug delivery system of tacrolimus. AAPS Pharm Sci Tech 2008; 9: 13-21.

38. Patel PV, Patel HK, Panchal S and Mehta T: Self micro emulsifying drug delivery system of tacrolimus: Formulation, in vitro evaluation and stability studies. Int J Pharma Investig 2013;3:95-104

39. Strickley G: Currently marketed oral lipid-based dosage forms: drug products and excipients, in D.J. Hauss (Ed.); oral lipid-based formulations-enhancing the bioavailability of poorly water-soluble drugs. Informa Healthcare, New York. 2007: 1-31. 
40. Shackleford DM: Contribution of lymphatically transported testosterone undecanoate to the systemic exposure of testosterone after oral administration of twoandriol formulations in conscious lymph ductcannulated dogs. J Pharmacol Exp Ther 2003; 306: 925-33.

41. Moen MD, Williamson $\mathrm{K}$ and Scott L: Liposomal amphotericin B: a review of its use as empirical therapy in febrile neutropenia and in treatment of invasive fungal infections. Int J Pharm 2008; 69: 361-392.

42. Website: www.Ambiosome.com

43. Griffin BT and Driscoll CM: A comparison of intestinal lymphatic transport and systemic bioavailability of saquinavir from three lipid-based formulations in the anesthetized rat model. J Pharm Pharmacol 2006; 58: 917925.

44. Larsson $\mathrm{K}$ and Ljusberg-Wahren $\mathrm{H}$ : Controlled release composition forming a reversed micellar (12) structure or a normal micellar (11) structure, US patent (US5906831A) (March 2002)
45. Vanderbist F, Deboeck A, Baudier P and Sereno A; Oral lipid-based pharmaceutical composition containing a composition of PPAR $\alpha$ and an HMG-COA reductase inhibitor, WO patent (WO2003013608A1) (Feb 2002)

46. Huatan $\mathrm{H}$ and Ross $\mathrm{R}$ : Pharmaceutical compositions adapted for oral delivery and optionally delivery in accordance with a circadian rhythm, US patent (US20110039814A1) (April 2009)

47. Lyons RT: Emulsion suitable for administering a sphingolipid, US patent (US5635536A) (March 2007)

48. Crison JR and Amidon GL; Method and formulation for increasing the bioavailability of poorly water-soluble drugs, US patent (US5993858A) (Nov.1999)

49. Liu R, Pan Q and Lee D: Formulations comprising lipidregulating agents, US patent (US6368620B2) (April 2002)

50. Patel JP, Sanzgiri YD, Lipari JM and Reiland TL: Novel formulations comprising lipid-regulating agents, WO patent (WO2000057859A) (March 2002)

How to cite this article:

Singh D: Lipid based drug delivery system: A review. Int J Life Sci \& Rev 2015; 1(11): 308-15. doi: 10.13040/IJPSR.09758232.IJLSR.1(11).308-15.

All @ 2015 are reserved by International Journal of Life Sciences and Review. This Journal licensed under a Creative Commons Attribution-NonCommercial-ShareAlike 3.0 Unported License.

This article can be downloaded to Android OS based mobile. Scan QR Code using Code/Bar Scanner from your mobile. (Scanners are available on Google Playstore) 